UDC 532.528

\title{
DYNAMICS OF A PARTIALLY CAVITATING UNDERWATER VEHICLE
}

\author{
V. N. Semenenko ${ }^{\dagger}$, O. I. Naumova \\ Institute of Hydromechanics of NAS of Ukraine \\ Zhelyabov Str., 8/4, 03057, Kyiv, Ukraine \\ ${ }^{\dagger}$ E-mail: vnsvns60@gmail.com
}

\begin{abstract}
Received 25.09.2017
The purpose of the paper is to analyze the peculiarities of the partially cavitating vehicle dynamics. The research method is a computer simulation using the approximation model of the unsteady supercavity basing on G. V. Logvinovich's principle of independence of supercavity's sections expansion. A method of determination of the balanced motion parameters for the partially cavitating vehicle is elaborated. The examples of computer simulation of the partially cavitating vehicle motion are given, incluing the vehicle speeding-up and deceleration. The longitudinal motion of the balanced partially cavitating vehicle is is shown to be statically unstable on depth. In this case, the motion stability loss occurs in "hard" non-oscillatory manner, unlike the supercavitation case. The methods of stabilizing the partially cavitating vehicle motion are proposed. The effect of cavity ventilation on the dynamics of the cavitating vehicle is studied.
\end{abstract}

KEY WORDS: partially cavitating vehicle, ventilated cavity, computer simulation

\section{INTRODUCTION}

The flow regime of planing within a supercavity, when a vehicle is fully located inside the cavity, is the optimal regime of the cruise motion of high-speed supercavitating vehicles (HSSV). The supercavitating vehicle dynamics has been studied for different control strategies in our previous works [1-5].

The vehicle motion in the partial cavitation regime, when a cavity covers only the part of the vehicle body, is possible when the vehicle speeding-up or deceleration, and also when maneuvering and when arising the unsteady cavity oscillation (see Fig. 1). Non-symmetry of the cavity shape and the line of the cavity closure on the body is caused by the inclination of both the cavitator plane and the body axis relatively to mainstream, and by the gravity action as well.

Many papers are devoted to studying the partial cavitation flow over hydrofoils and 3D bodies. In this case both the experimental and the numerical methods were applied. Papers [6-9] are devoted to investigation of the partial cavitation flows over 3D bodies. 
To attain the required small value of the cavitation number $\sigma$ for the specified motion depth and velocity $H, V$, the cavity pressure $p_{c}>p_{v}$ must be usually ensured (where $p_{v}=2.350 \mathrm{kPa}$ is the saturated vapor pressure), i.e., the cavity must be ventilated.

As opposed to the fully developed supercavities, the partial cavities always are essentially unsteady. There are two different mechanisms of the partial cavity instability. The first one is caused with periodic formation and destruction of a reentrant jet and occurs for both the vapour and the venti-

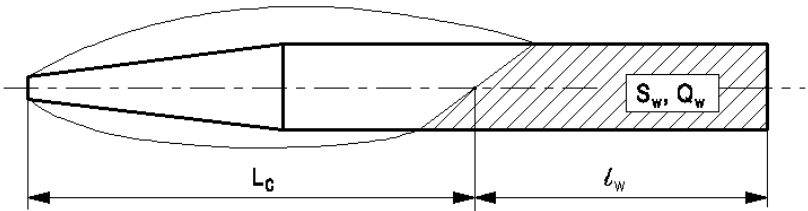

Fig. 1. Scheme of a partially cavitating vehicle lated cavities. It was experimentally established that blowing the gas into the cavity weakens this instability type [9].

In practical calculations (in the mathematical model described below as well) this type of "natural" non-stationarity is usually neglected. In this case the cavity shape and the rate of gas loss from the cavity $\dot{Q}_{\text {out }}$ are averaged by time, and the cavities are considered as steady ones.

The second cause of unsteady behaviour of the partial cavities is connected with the stability loss and arising the ventilated cavity pulsation when exceeding some critical magnitude of the similarity parameter $\beta=\sigma_{v} / \sigma$ (where $\sigma_{v}$ is the vapour cavitation number) $[10,11$. The mathematical model described below takes this non-stationarity type into consideration.

Purpose of this article is to analyze peculiarities of dynamics of the high-speed underwater vehicles moving in the partial cavitation regime. The research method is the computer simulation of a cavitating body dynamics with using the approximation model of an unsteady supercavity basing on the G. V. Logvinovich principle of independence of the supercavity section expansion [12]. Practically important cases of longitudinal motion of the partially cavitating vehicle, its speeding-up and deceleration are considered.

\section{MATHEMATICAL MODEL OF 3D MOTION OF A PARTIALLY CAVI- TATING VEHICLE}

We accept the following assumptions when formulating the problem of calculation of the self-propelled cavitating vehicle dynamics:

- the vehicle body has a shape of an elongated body of revolution;

- the cavitator is a disk with diameter $D_{n}$;

- the vehicle mass $m$ and the engine thrust $F_{\mathrm{pr}}$ are fixed;

- both the angle of attach $\alpha$ and the sliding angle $\beta$ are always sufficiently small;

- the time dependence of all the forces acting is quasistationary.

The following forces and their moments relatively to the vehicle mass center must be taken into consideration in the partial cavitation case:

- the hydrodynamic force acting onto the cavitator and its moment $\vec{F}_{n}, \vec{M}_{n}$; 
- the gravity force of the vehicle $\vec{F}_{g}=-m g$ (it does not create moment);

- the hydrostatic buoyancy (Archimedean) force and its moment acting onto the wetted part of the vehicle $\vec{F}_{a}, \vec{M}_{a}$;

- the skin friction drag and the transversal hydrodynamic force and its moment arising in case of flowing the vehicle with angles of attack and/or sliding $\vec{F}_{b}, \vec{M}_{b}$;

- the inertial force and moment acting on the wetted part of the vehicle $\vec{F}_{i}, \vec{M}_{i}$;

- the thrust of the engine and its moment $\vec{F}_{\mathrm{cr}}, \vec{M}_{\mathrm{cr}}$.

Also, the control force on the fins and its moment $\vec{F}_{f}$, vec $M_{f}$ has to be added in problems on vehicle maneuvering.

In this case a set of vector equations of the vehicle motion has the form [13]:

$$
\begin{gathered}
m\left(\frac{d \vec{V}}{d t}+\vec{\omega} \times \vec{V}\right)=\vec{F}_{n}+\vec{F}_{b}+\vec{F}_{i}+\vec{F}_{a}+\vec{F}_{g}+\vec{F}_{\mathrm{pr}}, \\
\frac{d \vec{K}}{d t}+\vec{\omega} \times \vec{K}=\vec{M}_{n}+\vec{M}_{b}+\vec{M}_{i}+\vec{M}_{a}+\vec{M}_{\mathrm{pr}},
\end{gathered}
$$

where $\vec{V}=\left\{V_{x 1}, V_{y 1}, V_{z 1}\right\}$ is the velocity vector of the body mass center and its components in the body coordinates; $\vec{\omega}=\left\{\omega_{x 1}, \omega_{y 1}, \omega_{z 1}\right\}$ is the angular velocity vector relatively to the body mass center; $\vec{K}$ is the body kinetic moment.

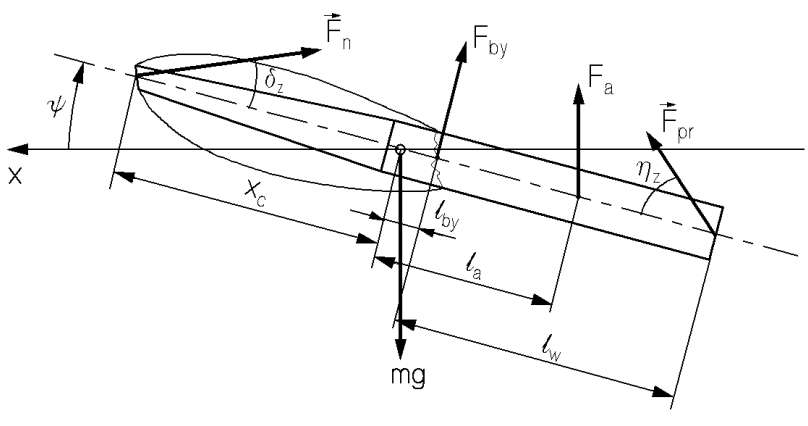

Fig. 2. Scheme of forces acting onto a partially cavitating vehicle in steady-state motion
The model position relatively to the Earth-fixed coordinates is defined by the pitch angle $\psi$, the yaw angle $\varphi$, and the roll angle $\theta$. The model position relatively to the flow coordinates is defined by the angle of attack $\alpha$ and the sliding angle $\beta$. Three kinematic Euler's relations [13] and three differentiation equations of motion of the vehicle mass center relatively to the fixed coordinates [4] have to be added to equations (1), (2).

The sum of the gravity and the hydrostatic force projections onto the axes of the body coordinates is as follows:

$$
\begin{gathered}
F_{g x}+F_{a x}=\left(F_{g}+F_{a}\right) \sin \psi, \\
F_{g y}+F_{a y}=\left(F_{g}+F_{a}\right) \cos \psi \cos \theta, \\
F_{g z}+F_{a z}=\left(F_{g}+F_{a}\right) \cos \psi \sin \theta,
\end{gathered}
$$

where $F_{g}=-m g ; F_{a}=\rho g Q_{w} ; Q_{w}$ is the volume of the wetted vehicle part. The Archimedean buoyancy force $F_{a}$ is applied to the center of the volume $Q_{w}$ located on the distance $x_{a}$ from 
the cavitator. Then projections of the moment of the force $\vec{F}_{a}$ relatively to the mass center are equal to:

$$
M_{a y}=F_{a z} l_{a}, \quad M_{a z}=F_{a y} l_{a}, \quad l_{a}=x_{c}-x_{a} .
$$

The skin friction drag of the wetted vehicle part is calculated by formulae:

$$
F_{b x}=-\frac{\rho V^{2}}{2} S_{w} c_{f}, \quad c_{f}=\frac{0.075}{\left(\lg \operatorname{Re}_{w}-2\right)^{2}}, \quad \operatorname{Re}_{w}=\frac{l_{w} V}{\nu},
$$

where $S_{w}$ is the area of the wetted vehicle part surface; $c_{f}$ is the skin friction coefficient in the turbulent boundary layer [14]; $\operatorname{Re}_{w}$ is the Reynolds number; $L_{c}$ is the average cavity length; $l_{w}=L-L_{c}$ is the average length of the wetted model part (see Fig. 2).

Components of the transversal hydrodynamic forces on the body $F_{b y}, F_{b z}$ for slender partially cavitating body will be the same as in the non-cavitating flow [12]:

$$
F_{b y}=2 \alpha \frac{\rho V^{2}}{2} S_{b}, \quad F_{b z}=-2 \beta \frac{\rho V^{2}}{2} S_{b}
$$

where $S_{b}$ is the model transom area. We have $\alpha=\psi, \beta=\varphi$ in the steady-state horizontal motion. One considers that the force $\vec{F}_{b}$ application point is located at the model transom [12]. Then projections of the moment of this force relatively to the model mass center are equal to:

$$
M_{b z}=F_{b y} l_{b}, \quad M_{b y}=-F_{b z} l_{b}, \quad l_{b}=x_{c}-L .
$$

Note that using the average length of the partial cavity in calculation is reasonable for sufficiently small angles $\alpha, \beta$ and not too small magnitudes of the Froude number. These conditions are usually fulfilled in practice.

The more precise method of the force determination when the non-symmetric cavity closes on the body basing on the method of plane section was proposed in monograph [15]. In this case the authors stated that the partially cavitating body motion is stable if the cavity length exceeds a half of the body length.

The inertial force and its moment expressed in terms of the added masses of the transversal flow $\lambda_{22}, \lambda_{33}$, etc. are essential in the unsteady flow over the vehicle in the partial cavitation regime. For vehicles having a shape of an elongated body of revolution the six coefficients of the generalized added masses are nonzero, and only three of them are independent: $\lambda_{22}=\lambda_{33}, \lambda_{26}=-\lambda_{35}, \lambda_{66}=\lambda_{55}$ [16]. The method of plane sections is used to calculate the added masses:

$$
\lambda_{22}=\rho \pi \int_{L_{c}}^{L} R^{2}(s) d s, \quad \lambda_{26}=\rho \pi \int_{L_{c}}^{L} R^{2}(s)\left(s-x_{c}\right) d s, \quad \lambda_{66}=\rho \pi \int_{L_{c}}^{L} R^{2}(s)\left(s-x_{c}\right)^{2} d s,
$$

where $R(x)$ is the current radius of the vehicle wetted part. Projections of the inertial force and moment onto the axes of the body coordinates are as follows [16]:

$$
\begin{gathered}
F_{i x}=-\lambda_{22}\left(\omega_{y} V_{z 1}-\omega_{z} V_{y 1}\right)+\lambda_{26}\left(\omega_{y}^{2}+\omega_{z}^{2}\right), \\
F_{i y}=-\lambda_{22} \frac{d V_{y 1}}{d t}-\lambda_{26} \frac{d \omega_{z}}{d t}, \\
F_{i z}=-\lambda_{22} \frac{d V_{z 1}}{d t}+\lambda_{26} \frac{d \omega_{y}}{d t},
\end{gathered}
$$




$$
\begin{aligned}
& M_{i y}=-\lambda_{55} \frac{d \omega_{y}}{d t}+\lambda_{26} \frac{d V_{z 1}}{d t}-\lambda_{26} V_{x 1} \omega_{y}+\lambda_{22} V_{x 1} V_{z 1}, \\
& M_{i z}=-\lambda_{55} \frac{d \omega_{z}}{d t}-\lambda_{26} \frac{d V_{y 1}}{d t}-\lambda_{26} V_{x 1} \omega_{z}-\lambda_{22} V_{x 1} V_{y 1} .
\end{aligned}
$$

The added mass of the longitudinal flow of the cavitating vehicle $\lambda_{11}$ is small in comparison with the vehicle mass $m$ and therefore it is not taken into consideration.

\section{COMPUTER SIMULATION OF THE CAVITATING VEHICLE DYNAM- ICS}

We accept the following assumptions when formulating the problem of calculation of unsteady behavior of the ventilated cavity:

- the first cavity instability type is not considered (see above);

- the cavity sections remain circular;

- the cavity gas expands isothermally;

- the cavity pressure $p_{c}$ is synchronously varied along the cavity.

A set of twelve equations of the solid body dynamics in projections onto the axes of the body coordinates is integrated numerically together with two equations describing the unsteady ventilated cavity evolution $[17,18]$ :

$$
\begin{gathered}
\frac{\partial^{2} S_{c}(\tau, t)}{\partial t^{2}}=-\frac{k_{1}}{2} V^{2}(\tau) \sigma(\tau, t), \\
\frac{d}{d t}\left[p_{c}(t) Q_{g}(t)\right]=p_{\infty}\left[\dot{Q}_{\text {in }}-\dot{Q}_{\text {out }}(t)\right],
\end{gathered}
$$

where $S_{c}$ is the cavity section area; $\tau \leq t$ is the instant of the section formation; $k_{1}$ is the constant; $Q_{g}=Q_{c}-Q_{b}$ is the cavity gas volume; $Q_{c}(t)$ is the cavity volume; $Q_{b}(t)$ is the volume of the body within the cavity; $\dot{Q}_{\text {in }}$ and $\dot{Q}_{\text {out }}$ are volumetric rates of the gas supply in the cavity and the gas loss from the cavity related to the water pressure $p_{\infty}$. The semiempirical formula is used to calculate the volumetric gas loss rate when the cavity closes on a body:

$$
\dot{Q}_{\text {out }}=C_{e}^{\prime} V \pi D_{b}^{2} \frac{L_{c}}{D_{n}} \operatorname{tg} \frac{\alpha_{b}}{2},
$$

where $\alpha_{b}$ is the average angle between the body contour and the cavity contour at the closure point; $C_{e}^{\prime}=0.28 \cdot 10^{-2}$ is the empirical coefficient that weakly depends on both the cavitation number and the body shape.

Also when calculation, the cavity axis curvature caused by the cavitator center displacement, the cavitator inclination, and the gravity acting [2] is taken into consideration.

The model having a shape described in paper [2] was used as the calculation model of the partially cavitating vehicle. Its main parameters are: the length $L=5 \mathrm{~m}$; the cylindrical part diameter $D_{b}=340 \mathrm{~mm}$; the cavitator diameter $D_{n}=70 \mathrm{~mm}$; the mass $m=600 \mathrm{~kg}$; 
the moments of inertia relatively to the vehicle axes $I_{x}=8 \mathrm{~kg} \cdot \mathrm{m}^{2}, I_{y}=I_{z}=900 \mathrm{~kg} \cdot \mathrm{m}^{2}$. The cruise motion parameters are: the velocity $V_{\text {cr }}=120.0 \mathrm{~m} / \mathrm{s}$; the depth $H=5.0 \mathrm{~m}$; the cavitation number $\sigma=0.02$; the gas rate coefficient $\dot{Q}_{\text {in }}=0.0013$; the cavity length $L_{\mathrm{cr}}=6.555 \mathrm{~m}$; the engine thrust $F_{\mathrm{cr}}=23.213 \mathrm{kN}$.

The underwater vehicle motion is called as balanced, if sum of all the forces acting and sum of all the moments are equal to zero. A method of numerical determination of balanced values of the cavitator inclination angles $\delta_{z}$, the thrust deflection angle $\eta_{z}$, and the pitch angle $\psi$ was proposed in work [1]. Tab. 1 gives the balanced values of the angles $\delta_{z}$ and $\psi$ when $\eta_{z}=0$ for a number of positions of the vehicle mass center $\bar{x}_{c}=x_{c} / L$ for the supercavitating vehicle motion in the cruise regime.

Table 1. Balanced angles $\delta_{z}$ and $\psi$ in the cruise regime (degrees)

\begin{tabular}{|c|c|c|c|}
\hline $\bar{x}_{c}$ & 0.4 & 0.5 & 0.6 \\
\hline$\delta_{z}^{*}$ & -8.760 & -7.260 & -5.779 \\
$\psi^{*}$ & 0.3902 & 0.3718 & 0.3538 \\
\hline
\end{tabular}

As is know, the longitudinal motion of the supercavitating vehicle in the regime of planing within a cavity is unstable on depth [1]. In this case a scenario of a "soft" stability loss is realized, when oscillation of the pitch angle $\psi$ and deflection of the model mass center from the straight path $y$ arise and then increase. Then on the cruise part the supercavitating vehicles need the motion depth-stabilization with an automatic error-closing control [1]:

$$
\delta_{z}(t)=\delta_{z}^{*}+k_{1} \bar{y}\left(t-t_{1}\right)+k_{2}\left[\psi\left(t-t_{1}\right)-\psi^{*}\right]+k_{3} \bar{\omega}\left(t-t_{1}\right) .
$$

where $\delta_{z}^{*}, \psi^{*}$ are the regulated values of the parameters; $k_{1}, k_{2}, k_{3}$ are the non-negative coefficients of feedback (transfer ratios of a regulator); $t_{1}$ is time of delay of the actuator reaction; $\bar{y}=y / L ; \bar{\omega}=\dot{\psi} L / V_{0}$; the angle are measured in radians. For this model in the cruise regime, the following values of transfer ratios are used: $k_{1}=2.0, k_{2}=5.0, k_{3}=0$.

\section{BALANCING A PARTIALLY CAVITATING VEHICLE}

A problem of determininig the balanced values of the angles $\delta_{z}, \eta_{z}$, and $\psi$ in the steadystate motion of the vehicle in the partial cavitation regime is solved numerically. In this case a set of equations for the model balance has the form:

$$
\begin{gathered}
F_{n x}+F_{b x}+F_{a x}+F_{g x}+F_{\mathrm{pr}} \cos \eta_{z}=0 \\
F_{n y}+F_{b y}+F_{a y}+F_{g y}+F_{\mathrm{pr}} \sin \eta_{z}=0 \\
M_{n z}+M_{b z}+M_{a z}+M_{\mathrm{pr} z}+M_{i z}=0
\end{gathered}
$$

where $M_{n z}=F_{n y} x_{c} ; M_{\mathrm{pr} z}=F_{\mathrm{pr}} \sin \eta_{z}\left(L-x_{c}\right) ; M_{i z}=-\lambda_{22} V_{x 1} V_{y 1}$. Eliminating $F_{\mathrm{pr}}$ from equations (15), we obtain a set of two functional equations with three unknowns:

$$
F_{1}\left(\delta_{z}, \eta_{z}, \psi\right)=0, \quad F_{2}\left(\delta_{z}, \eta_{z}, \psi\right)=0 .
$$

From these equations, fixing any of three angles $\delta_{z}, \eta_{z}, \psi$, one can determine the balanced values of two other angles. Let, for example, we want to determine the balanced values of 
angles $\delta_{z}^{*}, \psi^{*}$ for fixed $\eta_{z}$. For numerical solving a set of equations (16) we use the Newton's iteration algorithm: $\delta_{z}^{(i+1)}=\delta_{z}^{(i)}+\Delta \delta_{z}, \psi^{(i+1)}=\psi^{(i)}+\Delta \psi$, where additions $\Delta \delta_{z}, \Delta \psi$ for each iteration $i=1,2, \ldots$ are solution of a set of two linear equations:

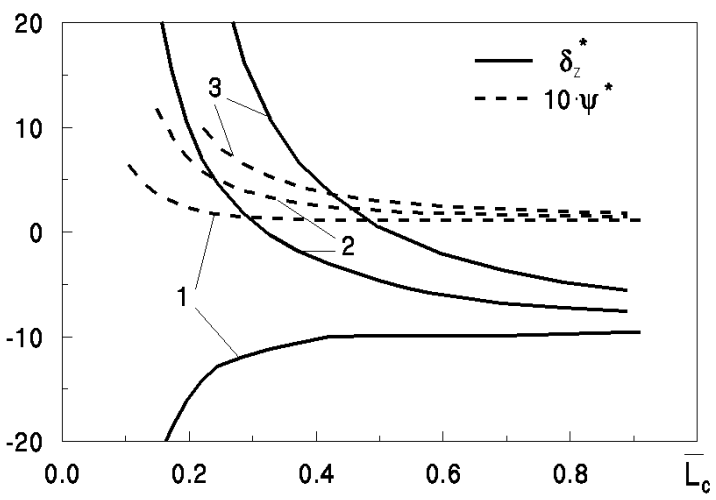

Fig. 3. Balanced values of angles $\delta_{z}$ and $\psi$ in the partial cavitation regime:

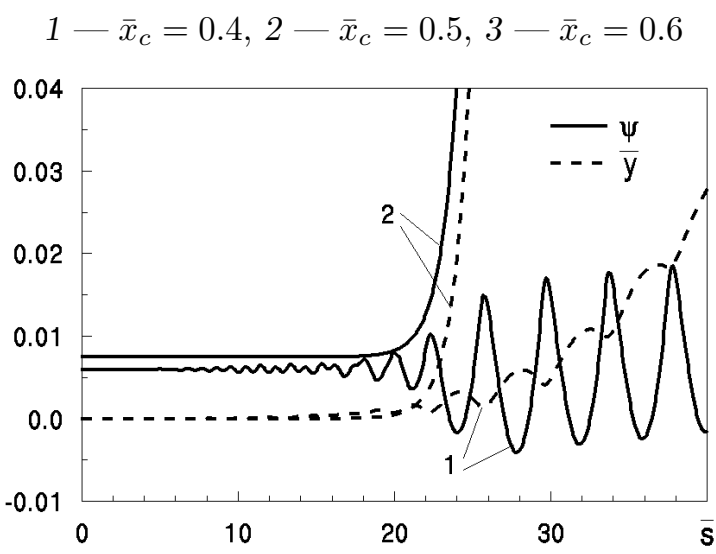

Fig. 4. Loss of the cavitating vehicle motion stability:

1 - the planing within a cavity regime, 2 - the partial caitation regime

$$
\begin{aligned}
& \frac{\partial F_{1}^{(i)}}{\partial \delta_{z}} \Delta \delta_{z}+\frac{\partial F_{1}^{(i)}}{\partial \psi} \Delta \psi=-F_{1}\left(\delta_{z}^{(i)}, \psi^{(i)}\right), \\
& \frac{\partial F_{2}^{(i)}}{\partial \delta_{z}} \Delta \delta_{z}+\frac{\partial F_{2}^{(i)}}{\partial \psi} \Delta \psi=-F_{2}\left(\delta_{z}^{(i)}, \psi^{(i)}\right) .
\end{aligned}
$$

Derivatives in the left parts of equations (17) are calculated numerically by the finite differences.

Fig. 3 gives the calculated dependencies $\delta^{*}\left(\bar{L}_{c}\right)$ and $\psi^{*}\left(\bar{L}_{c}\right)$ for the fixed $\eta_{z}=0$ for three position of the mass center $\bar{x}_{c}$ (the angles are in degrees). Magnitudes $\bar{L}_{c}=$ 0.5 and $\bar{L}_{c}=0.9$ corresponds to the vehicle velocity magnitudes $V_{0}=90 \mathrm{~m} / \mathrm{s}$ and $V_{0}=110 \mathrm{~m} / \mathrm{s}$, respectively, when the motion depth is $H=5 \mathrm{~m}$.

One should note that the range of values $\bar{x}_{c}$, for which the cavitating vehicle may be balanced for the specified values of the parameters $m$ and $\eta_{z}$, is decreased with decreasing the cavity length.

Also, the described algorithm is applicable for determining the balanced parameters for the case of the supercavitating vehicle in the regime of planing within a cavity, and it is even more effective than the earlier

method [1].

\section{LONGITUDINAL MOTION OF A PARTIALLY CAVITATING VEHICLE}

We consider first a case of the longitudinal motion of the balanced partially cavitating vehicle when the engine thrust is equal to the total hydrodynamic drag: $F_{\mathrm{pr}}=-F_{x}$.

Fig. 4 gives graphs of dependence of the pitch angle $\psi$ (in degrees) and the mass center deflection $\bar{y}=y / L$ from the flight path $\bar{s}=s / L$ in the longitudinal motion of both the supercavitating and the partially cavitating models. In both cases the calculation was performed for the initial balanced magnitudes of the parameters when $\bar{x}_{c}=0.6$.

As is seen, the longitudinal motion of the balanced partial cavitating model is statically unstable on depth. In this case the stability loss of the vehicle motion occurs in the "hard" non-oscillatory manner, and the more is the average cavity length $L_{c}$, the more is 
the model "stability margin". For the unbalanced vehicle, variations of the parameters $\psi, y$ are proportional to the starting deviations of parameters from their balanced values.

One can consider that when $L_{c} \ll L$, the partially cavitating vehicle dynamics is similar to dynamics of a non-cavitating elongated body of revolution. As is known, it is statically unstable owing to action of the overturning moment $M_{i z}$. In practice, passive stabilization of the elongated body motion in non-cavitating flow is realized with the tail fins. It seems, the tail fins may be applied for passive stabilization of motion of the partially cavitating vehicles as well.

The computer simulation has shown that one can successfully apply the automatic errorclosing $\delta$-stabilization on depth similar to one described in our paper [1] to active stabilize the longitudinal motion of the partially cavitating vehicle. In this case the law of automatic regulation of the cavitator inclination angle has the form:

$$
\delta_{z}(t)=\delta_{z}^{*}+k_{2}\left[\psi(t)-\psi^{*}\right]+k_{3} \bar{\omega}(t),
$$

where $k_{2}>0, k_{3}>0$ are the regulator transfer ratios. It was established that, in difference from the supercavitating vehicle case, one does need directly regulate deflection of the vehicle mass center on depth $y$ in the case of partially cavitating vehicle (i.e., $k_{1} \equiv 0$ in (14).

It should be noted that the optimal values of the transfer ratios $k_{2}, k_{3}$ may be varied in dependence on a number of the parameters, especially $x_{c}$ and $L_{c}$. In paricular, the values $k_{2}=5.0, k_{3}=20.0$ ensure stable motion for a wide range of values $x_{c}, L_{c}$ for this calculated model.

Also, computer simulation has shown that longitudinal motion of the partially cavitating vehicles (i.e., when $\delta_{y}=0$ and $\varphi=0$ ) is stable on course. The same is true for supercavitating vehicles. If the starting values $\delta_{y}(0) \neq 0$ and/or $\varphi(0) \neq 0$, then variation of the parameters $\varphi(t), z(t)$ in the vehicle lateral motion is proportional to the starting deviation of the parameters $\delta_{y}, \varphi$ from zero.

\section{CAVITATING VEHICLE DYNAMICS DURING SPEEDING-UP}

The cavity development up to its length $L_{c}$ corresponding to the cruise regime with the velocity $V_{\text {cr }}$ must be ensured during speeding-up the cavitating vehicle from the low starting velocity. In our paper [19], the speeding-up process has been studied with the assumption that the model path is straight-line (as when testing the models on the cable launching tank [20]) und the cavity is axisymmetric. Consider now the speeding-up process with taking into account the dynamics of the partially cavitating vehicle by equations (1), (2). In this case calculation of possible deviations of the parameters $\psi, \varphi, y, z$ on the speeding-up part and elaboration of methods of their stabilization are of the practical interest.

Paper [19] shows that a starting engine with the thrust $F_{s t}$ exceeding in about five times the cruise engine thrust $F_{\text {cr }}$ is required to accelerate this cavitating vehicle model with the admissible maximal overload $\bar{a}=a / g \approx 20$. The following starting parameters were accepted in calculation: $V(0)=10 \mathrm{~m} / \mathrm{s} ; p_{c}(0)=2.350 \mathrm{kPa}$, in this case we have $\sigma(0)=2.894$; $L_{c}=0.130 \mathrm{~m}$.

Computer simulation has shown that when speeding-up the balanced model its "stability margin" usually is sufficient up to the acceleration part end, and in this case deviations of the parameters $\psi, y$ are very small. After finishing the speeding-up, the system of stabilization of the balanced cruise parameters (14) must be turned on. 

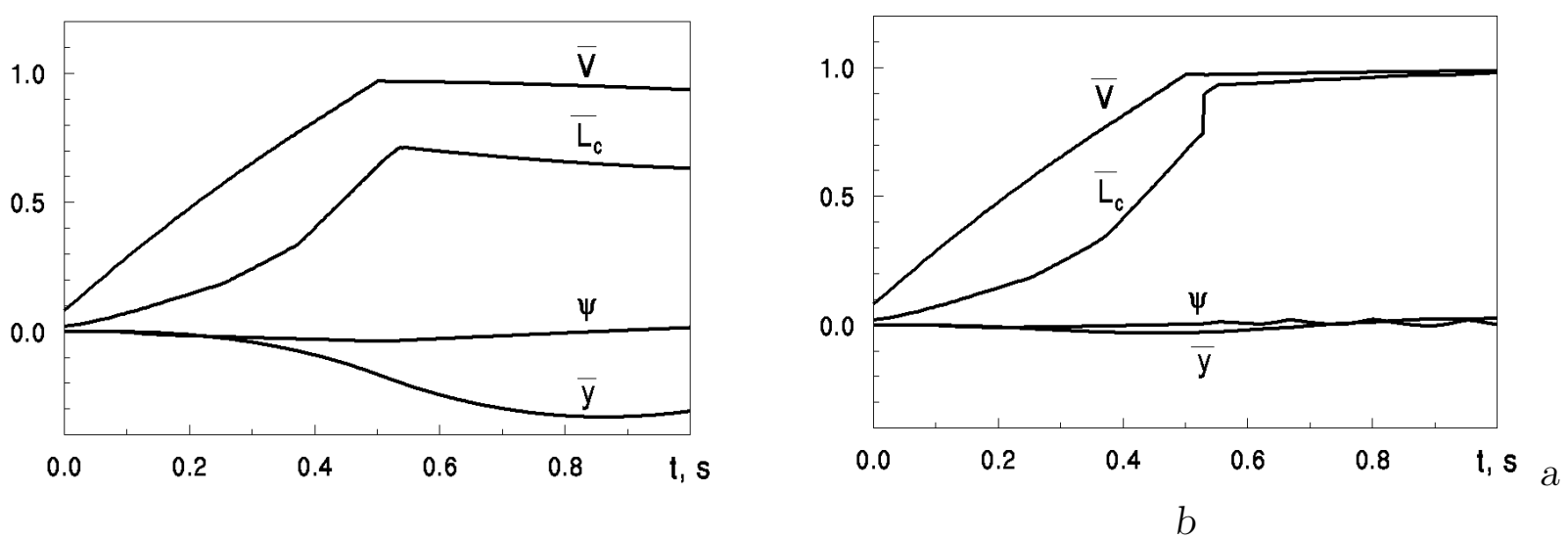

Fig. 5. Variation of motion parameters during speeding-up:

a - without stabilization, $b$ - with $\delta$-stabilization on depth

On the contrary, at presence of starting imbalance of the model motion the deviations on the acceleration part may become inadmissibly large. Fig. 5a gives graphs of varying the parameters $\bar{V}=V(t) / V_{\mathrm{cr}}, \bar{L}_{c}=L_{c}(t) / L_{\mathrm{cr}}, \psi, \bar{y}$ on the interval $0<t<1 \mathrm{~s}$. The following initial values of the parameters were accepted in calculation: $\delta_{z}=0, \psi=0$. The starting engine with thrust $F_{s t}=150 \mathrm{kN}$ is turned off at instant $t=0.5 \mathrm{~s}$, then the cruise engine is turned on.

As is seen, in this case the cruise values $L_{\mathrm{cr}}, V_{\mathrm{cr}}$ are not attained, what is explained by increasing the motion depth $H=H_{0}-y$. The graphs of variation of the same parameters for the same conditions but when operating $\delta$-stabilization on depth (14) is given in Fig. 5b. In this case the complete speeding-up the cavitating vehicle occurs on the same interval 0.5 s with the small deviations of the parameters $\psi, y$.

The cavity development during speeding-up of the cavitating vehicle may be accelerated by increasing the rate of gas-supply into the cavity $\dot{Q}_{\text {in }}$. However, in this case the cavity evolution will be increasingly influenced by dynamic properties of gas-filled cavities. As was shown in $[10,11]$, when exceeding the some critical value of the similarity parameter $\beta=\sigma_{v} / \sigma$ (where $\sigma_{v}$ is the vapour cavitation number) the cavity loses stability and begins to pulsate intensively. In this case the rate of gas-loss from the cavity $\dot{Q}_{\text {out }}$ increases, and that prevents next increasing the average cavity length. It was concluded in work [19] that the effectiveness of the increased gas-supply during speeding-up the supercavitating vehicle is weak, and it decreases when the starting engine thrust increases.

\section{CAVITATING VEHICLE DYNAMICS DURING DECELERATION}

The cavity evolution law and law of the vehicle velocity reduction after turning off the cruise engine is of practical interest. At transition from the supercavitating regime to the partial cavitation regime the vehicle becomes imbalanced in the general case. In this case, the non-stationary transversal forces begin to act on the vehicle, so that the deviations of the motion parameters from specified ones may rapidly exceed the admissible values.

Fig. 6 gives graphs of varying the model velocity $V$, the cavity length $L_{c}$, and the angle of attack $\alpha$ (in radians) in the model motion on inertia after the cruise engine turning off. It is assumed in this case that the gas supply into the cavity is not changed, and the depth 
stabilization system continues to operate.

In this calculation, the balanced parameter values for the cruise regime are used as the initial data (see Tab. $1, \bar{x}_{c}=0.6$ ). On the time interval $0<t<2.0$ s the model enters on the regime of steady oscillation of the pitch angle with the frequency $6.562 \mathrm{~Hz}$. At instant $t=2.0 \mathrm{~s}$ the cruise engine is turned off, after this the model moves on inertia. In this case both the velocity and the cavity length decrease. The calculation was perormed to instant $t=2.71 \mathrm{~s}$, when the model angle of attack exceeds the admissible value $\alpha=7^{\circ}$.

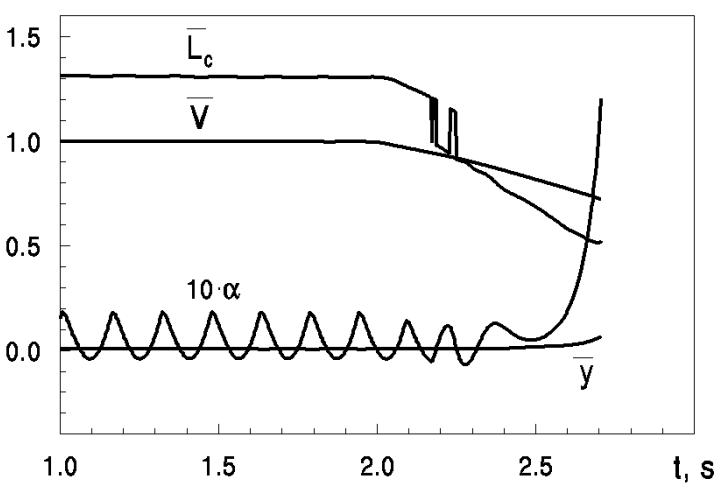

Fig. 6. Variation of motion parameters after the cruise engine turning-off

As is seen, the motion on inertia of the partially cavitating vehicle without fins rapidly loses the static stability. Computer simulation has shown that in this case the motion can not be stabilized by means of the automatic $\delta$-control (18). It seems, in practice the motion may be stabilized by opening or extending the tail fins from the vehicle body.

\section{EFFECT OF CAVITY VENTILATION ON THE CAVITATING VEHICLE DYNAMICS}

As it was said above, in practice one has to blow gas into a cavity (i.e., to ventilate a cavity) for ensuring required cavity dimensions for specified magnitudes of the velocity and depth $V, H$ of the supercavitating vehicle motion. During speeding-up the vehicle, the cavity development may be accelerated by increasing the gas-supply rate $\dot{Q}_{\text {in }}$.

Obvious effect of the gas-supply rate onto the cavitating vehicle dynamics is explained by the cavity dimensions and shape variation at the cavity ventilation. In this case the forces of interaction of the vehicle with water are changed for both the partially cavitating vehicles and the supercavitating vehicles moving in the planing within a cavity regime.

Consider the cavitating vehicle motion with the same depth $H$ and the same cavitation number $\sigma$, but with different velocities $V$. In these cases, the dynamical similarity of flow will be disturbed because of the cavity shape distortion under gravity action owing to changing the Froude number Fr, and also owing to possible unsteady behavior of the ventilated cavity. In this case the balanced values of the angles $\delta_{z}, \psi, \eta_{z}$ and other parameters will be changed,

Table 2. Parameters of the partially cavitating vehicle steady-state motion:

$$
H=5.0 \mathrm{~m} ; \eta_{z}=0 ; \sigma=0.03
$$

\begin{tabular}{|c|c|c|c|c|c|}
\hline$V, \mathrm{~m} / \mathrm{s}$ & $\delta_{z}^{*}$ & $\psi^{*}$ & $\operatorname{Fr}$ & $\beta$ & $\bar{Q}_{\text {in }}$ \\
\hline 50.0 & -10.905 & 0.8835 & 60.35 & 3.880 & 0.2000 \\
70.0 & -6.262 & 0.4463 & 84.49 & 1.966 & 0.2181 \\
90.0 & -3.770 & 0.2711 & 108.6 & 1.189 & 0.2255 \\
\hline
\end{tabular}


and this leads to additional cavity shape distortion (see Tab. 2).

The table has nomenclature: $\mathrm{Fr}=V / \sqrt{g D_{n}}$ is the Froude number; $\bar{Q}_{\text {in }}=\dot{Q}_{\text {in }} / V D_{n}^{2}$ is the coefficient of the gas-supply rate.

Fig. 7 gives graphs of varying the parameters $\psi, \bar{y}$ for the range $0<t<10 \mathrm{~s}$. The calculation was performed for starting magnitudes of the parameters $V, H, \delta_{z}, \psi$ from Tab. 2 with turned-on $\delta$-stabilization on depth (14).

In the first case we have $\beta>\beta_{\mathrm{cr}}$, therefore the ventilated cavity rapidly loses stability and begins to pulsate (see $[10,11]$ ). As a result, the "hard" instability of the partially cavitating vehicle motion is developed in spite of the $\delta$-stabilization. In the second case and in the third case we have $\beta<\beta_{\mathrm{cr}}$, and perturbations arising at the $\delta$-stabilization system operation are damped with the lapse of time.

\section{CONCLUSIONS}

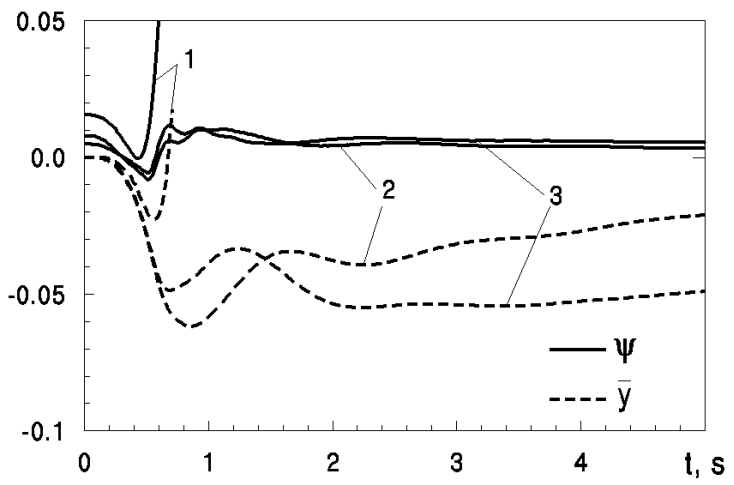

Fig. 7. Variation of motion parameters at different gas-supply rates:

$1-V=50.0 \mathrm{~m} / \mathrm{s}, 2-V=70.0 \mathrm{~m} / \mathrm{s}$, $3-V=90.0 \mathrm{~m} / \mathrm{s}$

The mathematical model of 3D dynamics of the self-propelled partially cavitating underwater vehicle has been developed.

The method of determination of the balanced motion parameters of the partially cavitating vehicle is elaborated. Examples of computer simulation of the partially cavitating vehicle motion (especially for both the vehicle speeding-up and deceleration) are given.

The performed computer simulation has shown that the longitudinal motion of the balanced partially cavitating vehicle is statically unstable on depth. In this case the motion stability loss occurs in "hard" nonoscillatory manner unlike the supercavitation case.

The deviations of parameters $\psi, \varphi, y, z$ during the speeding-up depend on degree of the starting imbalance of the cavitating vehicle and can become unacceptably large. Thus, the partially cavitating vehicle motion requires in additional depth stabilization like the supercavitating vehicle motion. It has been shown that the same error-closing control system as for the supercavitating vehicles may be successfully applied to stabilize the partially cavitating vehicle motion for both the fixed velocity and the speeding-up.

It has been shown that the ventilated cavity shape distortion and their unsteady behaviour with the same cavitation number but with different gas-supply rates can influence essentially onto the cavitating vehicle dynamics. This conclusion is valid for both the partially cavitating vehicles and the supercavitating vehicles moving in the planing within a cavity regime. 


\section{ЛITEPATУРA}

[1] Семененко В. Н. Моделирование продольного движения подводных суперкавитирующих аппаратов // Прикладная гидромеханика. - 2010. - Т. 12(84), № 4. - С. 8188.

[2] Semenenko V. N., Naumova Y. I. Study of the supercavitating body dynamics // Supercavitation: Advances and perspectives. - Berlin and Heidelberg : Springer-Verlag, 2012. - P. 147-176.

[3] Савченко Ю. Н., Семененко В. Н. О маневренности по курсу подводных суперкавитирующих аппаратов // Прикладная гидромеханика. - 2011. - Т. 13(85), № 1. C. $43-50$.

[4] Семененко В. Н. Расчет пространственного движения суперкавитирующих аппаратов // Прикладная гидромеханика. - 2012. - Т. 14(86), № 4. - С. 79-82.

[5] Семененко В. Н. Исследование динамики и управления движением суперкавитирующих тел на основе теории Г. В. Логвиновича // Прикладная гидромеханика. 2013. - T. 15(87), № 1. - C. 83-93.

[6] Varghese A. N., Uhlman J. S., Kirschner I. N. High-speed bodies in partially cavitating axisymmetric flow // Fifth International Symposium on Cavitation (CAV2003).Osaka, Japan, 2003.

[7] Kim S., Kim N. Integrated dynamics modeling for supercavitating vehicle systems // International Journal of Naval Architecture and Ocean Engineering. - 2015. - Vol. 7. P. 346-363.

[8] Nouroozi M., Pasandidehfard M., Djavareshkian M. H. Simulation of partial and supercavitating flows around axisymmetric and quasi-3D bodies by boundary element method using simple and reentrant jet models at the closure zone of cavity // Mathematical Problems in Engineering. - 2016. - Vol. 2016, no. 1593849. - P. 1-13.

[9] Yiwei W., Xiaocui W., Chenguang H. Ventilated partial cavitating flow around a blunt body near the free surface // Proceedings of International Symposium on Transport Phenomena and Dynamics of Rotating Machinery. - Honolulu, Hawaii, 2016.

[10] Семененко В. Н. Неустойчивость вентилируемой каверны при замыкании на теле // Прикладная гидромеханика. - 2011. - Т. 13(85), № 3.- С. 76-81.

[11] Семененко В. Н. Пульсации вентилируемых каверн при различных условиях замыкания // Прикладная гидромеханика. - 2011. - Т. 13(85), № 4. - С. 62-67.

[12] Логвинович Г. В. Гидродинамика течений со свободными границами. - K. : Наукова думка, 1969. - С. 215.

[13] Поляков Н. Н., Зегжда С. А., Юшков М. П. Теоретическая механика. - М. : Высшая школа, 2000. - 592 с. 
[14] Schlihting H. Boundary layer theory.-- New York : McGraw-Hill, 1961.

[15] Дегтярь В. Г., Пегов В. И. Гидродинамика баллистических ракет подводных лодок. - Миасс : КБ им. акад. В. П. Макеева, 2004. - 256 с.

[16] Короткин А. И. Присоединенные массы судна. Справочник. - Л. : Судостроение, 1986. - 312 c.

[17] Логвинович Г. В., Серебряков В. В. О методах расчета формы тонких осесимметричных каверн // Гидромеханика. - 1975. - Т. 32. - С. 47-54.

[18] Парышев Е. В. Теоретическое исследование устойчивости и пульсаций осесимметричных каверн // Труды ЦАГИ. - 1978. - № 1907. - С. 17-40.

[19] Савченко Ю. Н., Семененко В. Н. Движение суперкавитирующего аппарата на подводном участке разгона // Прикладная гидромеханика. - 2015. - Т. 17(89), № 4. C. $36-42$.

[20] Vlasenko Y. D. Experimental investigations of supercavitating regime of flow around self-propelled models // International Journal of Fluid Mechanics Research. - 2001. Vol. 28, no. 5. - P. 717-733.

\section{REFERENCES}

[1] V. N. Sememenko, "Modelling of the longitudinal motion of the underwater supercavitating vehicles," Applied Hydromechanics, vol. 12(84), no. 4, pp. 81-88, 2010.

[2] V. N. Semenenko and Y. I. Naumova, "Study of the supercavitating body dynamics," in Supercavitation: Advances and perspectives, pp. 147-176, Berlin and Heidelberg: Springer-Verlag, 2012.

[3] Y. N. Savchenko and V. N. Semenenko, "On the course maneuvering of underwater supercavitating vehicles," Applied Hydromechanics, vol. 13(85), no. 1, pp. 43-50, 2011.

[4] V. N. Semenenko, "Calculation of 3D motion of supercavitating vehicles," Applied Hydromechanics, vol. 14(86), no. 4, pp. 79-82, 2012.

[5] V. N. Semenenko, "Analysis of the supercavitation body dynamics and control basing on the G. V. Logvinovich theory," Applied Hydromechanics, vol. 15(87), no. 1, pp. 83-93, 2013.

[6] A. N. Varghese, J. S. Uhlman, and I. N. Kirschner, "High-speed bodies in partially cavitating axisymmetric flow," in Fifth International Symposium on Cavitation (CAV2003), (Osaka, Japan), 2003.

[7] S. Kim and N. Kim, "Integrated dynamics modeling for supercavitating vehicle systems," International Journal of Naval Architecture and Ocean Engineering, vol. 7, pp. 346-363, 2015. 
[8] M. Nouroozi, M. Pasandidehfard, and M. H. Djavareshkian, "Simulation of partial and supercavitating flows around axisymmetric and quasi-3D bodies by boundary element method using simple and reentrant jet models at the closure zone of cavity," Mathematical Problems in Engineering, vol. 2016, no. 1593849, pp. 1-13, 2016.

[9] W. Yiwei, W. Xiaocui, and H. Chenguang, "Ventilated partial cavitating flow around a blunt body near the free surface," in Proceedings of International Symposium on Transport Phenomena and Dynamics of Rotating Machinery, (Honolulu, Hawaii), 2016.

[10] V. N. Sememenko, "Instability of ventilated cavity that is closed on a body," Applied Hydromechanics, vol. 13(85), no. 3, pp. 76-81, 2011.

[11] V. N. Sememenko, "Pulsation of ventilated cavities at various closure conditions," Applied Hydromechanics, vol. 13(85), no. 4, pp. 62-67, 2011.

[12] G. V. Logvinovich, Hydrodynamics of flows with free boundaries. Kiev: Naukova Dumka, 1969.

[13] N. N. Polyakov, S. A. Zegzhda, and M. P. Yushkov, Theoretical mechanics. Moscow: Vysshaya Shkola, 2000.

[14] H. Schlihting, Boundary layer theory. New York: McGraw-Hill, 1961.

[15] V. G. Degtyar and V. I. Pegov, Hydrodynamics of ballistic missiles for submarines. Miass: Makeyev Rocket Design Bureau, 2004.

[16] A. I. Korotkin, Added masses of a ship: Handbook. Leningrad: Sudostroenie, 1986.

[17] G. V. Logvinovich and V. V. Serebryakov, "On the methods of calculating a shape of the slender axisymmetric cavities," Hydromechanics, vol. 32, pp. 47-54, 1975.

[18] E. V. Paryshev, "Theoretical investigation of stability and pulsations of axisymmetric cavities," Trudy TsAGI, no. 1907, pp. 17-40, 1978.

[19] Y. N. Savchenko and V. N. Semenenko, "Motion of supercavitating vehicle during underwater speeding-up," Applied Hydromechanics, vol. 17(89), no. 4, pp. 36-42, 2015.

[20] Y. D. Vlasenko, "Experimental investigations of supercavitating regime of flow around self-propelled models," International Journal of Fluid Mechanics Research, vol. 28, no. 5, pp. 717-733, 2001.

\section{В. М. Семененко, О. I. Наумова \\ Динаміка частково кавітуючого підводного апарата}

Метою роботи є аналіз особливостей динаміки частково кавітуючих апаратів. Метод дослідження - комп'ютерне моделювання з використанням апроксимаційної моделі нестаціонарної суперкаверни, яка базується на принципі незалежності розширення перерізів каверни Г. В. Логвиновича. Розроблено метод знаходження рівноважних значень параметрів руху частково кавітуючого апарата. Наведено приклади комп'ютерного моделювання руху частково кавітуючого апарата, зокрема 
при його розгоні і гальмуванні. Показано, що поздовжній рух збалансованого частково кавітуючого апарата статично нестійкий по глибині. При цьому втрата стійкості руху, на відміну від випадку суперкавітації, відбувається "жорстким" неколивальним чином. Запропоновано способи стабілізації руху частково кавітуючого апарата. Досліджено вплив вентиляції каверни на динаміку кавітуючого апарата.

КЛЮЧОВІ СЛОВА: частково кавітуючий апарат, вентильована каверна, стійкість, комп'ютерне моделювання

\section{В. Н. Семененко, О. И. Наумова}

Динамика частично кавитирующего подводного аппарата

Целью работы является анализ особенностей динамики частично кавитирующих аппаратов. Метод исследования - компьютерное моделирование с использованием аппроксимационной модели нестационарной суперкаверны, основанной на принципе независимости расширения сечений каверны Г. В. Логвиновича. Разработан метод нахождения равновесных значений параметров движения частично кавитирующего аппарата. Приведены примеры компьютерного моделирования движения частично кавитирущего аппарата, в частности при его разгоне и торможении. Показано, что продольное движение сбалансированного частично кавитирующего аппарата статически неустойчиво по глубине. При этом потеря устойчивости движения, в отличие от случая суперкавитации, происходит "жестким" неколебательным образом. Предложены способы стабилизации движения частично кавитирующего аппарата. Исследовано влияние вентиляции каверны на динамику кавитирующего аппарата.

КЛЮЧЕВЫЕ СЛОВА: частично кавитирующий аппарат, вентилируемая каверна, устойчивость, компьютерное моделирование 